\title{
Shallow water as a refuge habitat for fish and crustaceans in non-vegetated estuaries: an example from Chesapeake Bay
}

\author{
Gregory M. Ruiz ${ }^{1}$, Anson H. Hines ${ }^{1}$, Martin H. Posey ${ }^{2}$ \\ ${ }^{1}$ Smithsonian Environmental Research Center, PO Box 28, Edgewater, Maryland 21037, USA \\ ${ }^{2}$ Department of Biological Sciences, University of North Carolina at Wilmington, Wilmington, North Carolina 28403, USA
}

\begin{abstract}
Abundances and size-frequency distributions of common epibenthic fish and crustaceans were compared among 3 depth zones $(1-35,35-70,71-95 \mathrm{~cm})$ of the Rhode River, a subestuary of Chesapeake Bay, USA. In the absence of submerged aquatic vegetation (SAV), inter- and intraspecific size segregation occurred by depth from May to October, 1989-1992. Small species (Palaemonetes pugio, Crangon septemspinosa, Fundulus heteroclitus, F. majalis, Rhithropanopeus harrisii, Apeltes quadracus, Gobiosoma bosci) were most abundant at water depths $<70 \mathrm{~cm}$. Furthermore, the proportion of small individuals decreased significantly with depth for 7 of 8 species, with C. septemspinosa being the exception, exhibiting no size change with increasing depth. These distributional patterns were related to depth-dependent predation risk. Large species (Callinectes sapıdus, Leiostomus xanthurus, and Micropogonias undulatus), known predators of some of the small species, were often most abundant in deep water $(>70 \mathrm{~cm})$. In field experiments, mortality of tethered $P$ pugio $(30$ to $35 \mathrm{~mm})$, small $F$. heteroclitus $(40$ to $50 \mathrm{~mm})$, and small $C$. sapidus $(30$ to $70 \mathrm{~mm}$ ) increased significantly with depth. We hypothesize that predation risk was size-dependent, creating the observed intra- and interspecific size differences among depth zones. For $C$. septemspinosa, burial may modify this size-dependency and create the unusual absence of intraspecific size increase with depth. Historically, $P$. pugio and Fundulus spp. (and other small species) were not restricted to shallow $(<70 \mathrm{~cm}$ ) waters and were abundant in deeper SAV beds, which provided a structural refuge from predators. Since the recent demise of SAV in Chesapeake Bay, our results indicate many small species have shifted their distributions and now utilize primarily shallow water as an alternate refuge habitat.
\end{abstract}

\section{INTRODUCTION}

Non-vegetated sediments often dominate the bottom area of estuaries, and the extent of non-vegetated substrate has increased historically in many estuaries, especially during periods of rapid decline in the abundance of submerged aquatic vegetation (SAV) (e.g. Pérès \& Picard 1975, Rasmussen 1977, Orth \& Moore 1984, Muehlstein 1989, Shepherd et al. 1989). Despite a frequent prominence of non-vegetated sediments in estuaries, the importance of submerged aquatic vegetation to the structure and dynamics of animal communities has been emphasized (e.g. Orth et al. 1984 and references therein). In particular, the value of SAV as a refuge from predation has probably received most attention in both estuarine (e.g. Heck \& Thoman 1981 ,
Peterson 1982, Summerson \& Peterson 1984, Wilson et al. 1987, Rozas \& Odum 1988, Bell \& Pollard 1989) and freshwater systems (e.g. Werner et al. 1983, Holomuzki 1986, Mittelbach 1986, Foster et al. 1988, Savino \& Stein 1989) (but see also Kemp et al. 1984 and Orth et al. 1984 for discussion of other roles of SAV). However, the importance of other (alternate) refuge habitats in estuaries is poorly resolved when SAV is absent or occurs in low abundance.

For Chesapeake Bay (USA), SAV has historically undergone great fluctuations in abundance and species composition, and is now scarce relative to the recent past (e.g. Bayley et al. 1978, Stevenson \& Confer 1978, Orth \& Moore 1984). Although SAV persists in large but diminished beds in the lower Bay, submerged vegetation is now nearly absent through- 
out most of the upper Chesapeake Bay. An extensive literature documents the utilization of SAV by, and its importance to, the fauna of Chesapeake Bay (e.g. see review by Orth et al. 1984; also Heck \& Thoman 1984, Kemp et al. 1984, Rozas \& Odum 1987a, Sogard \& Abele 1991). With the exception of documented declines in abundance of waterfowl and scallop populations (Stevenson \& Confer 1978, Perry \& Uhler 1988), data are not available which evaluate potential changes in abundance, habitat utilization, diet, size structure, and dynamics of animal populations due to declines in $\mathrm{SAV}_{i}$ rather, the literature implies erroneously that the present-day ecology of Chesapeake Bay fauna is strongly associated with SAV.

This paper examines the distribution of highly mobile epibenthic fish and crustacean species, associated historically with SAV, in a non-vegetated subestuary of Chesapeake Bay. Specifically, we examined utilization of shallow water as a refuge from predators in the absence of SAV. Our goal was to characterize the composition and distribution of species in shallow water, and begin to evaluate the refuge value of shallow water.

Our study included the entire epibenthic community and we focused intensively on mummichogs Fundulus heteroclitus, grass shrimp Palaemonetes pugio, and juvenile blue crabs Callinectes sapidus as model species likely to utilize shallow water as refuge. These 3 species are abundant in Chesapeake Bay (Heck \& Orth 1980, Orth \& Heck 1980, Heck \& Thoman 1984, Everett \& Ruiz 1993), and other estuaries along the Atlantic coast of North America (Nixon \& Oviatt 1973, Welsh 1975, Valiela et al. 1977, Weinstein 1979, Roundtree \& Abele 1992), where they are functionally important in estuarine food webs and community dynamics (Bell \& Coull 1978, Virnstein 1979, Kneib 1985, 1988, Posey \& Hines 1991, Eggleston et al. 1992). Besides their frequent association with SAV (e.g. Heck \& Orth 1980 Orth \& Heck 1980, Heck \& Thoman 1984, Orth \& van Montfrans 1987), all 3 species are often found in shallow $(<1 \mathrm{~m})$ water and are known to utilize intertidal habitats with emergent vegetation (Kneib 1984a, b, Rozas \& Hackney 1984, Rozas \& Odum 1987C, Fitz \& Wiegert 1991). Use of shallow water is thought to reduce their risk of predation (Boesch \& Turner 1984, Kneib 1984b, Rozas \& Hackney 1984, Rozas \& Odum 1987b, McIvor \& Odum 1988), providing a refuge just as SAV does for each of these species (Coen et al. 1981, Heck \& Thoman 1981, Wilson et al, 1987, Rozas \& Odum 1988). In laboratory experiments, Posey \& Hines (1991) have further shown that grass shrimp prefer shallow water in the presence of fish predators, supporting the common belief that shallow water provides a refuge from predation for mobile epibenthic fauna. Our field data examine explicitly this relationship in the absence of SAV by testing 2 general hypotheses: (1) habitat utilization is restricted to shallow rather than deeper waters in the presence of predators; and (2) the risk of predation increases with increasing water depth

\section{METHODS}

Study sites. All field work was done at 2 study sites in the Rhode River (Fig. 1), a shallow subestuary of Chesapeake Bay with an average depth of $2 \mathrm{~m}$ and maximum depth of $4 \mathrm{~m}$ (Han 1974). Water temperature fluctuates seasonally between 2 and $30^{\circ} \mathrm{C}$, and salinity varies from 3 to 17 ppt (Hines et al. 1987a, pers. obs.); tidal amplitude is ca $0.5 \mathrm{~m}$ (Hines et al. 1985). Canning House Bay (CHB), the site of most work, is dominated by sand beaches with very little fringing marsh vegetation. Big Island (BI) has a shoreline with nearly continuous cover of Spartina patens. Although SAV occurred historically as late as the mid-1970s in the Rhode River (Southwick \& Pine 1975), the subtidal substrate at both sites and the entire subestuary is now composed almost exclusively of non-vegetated fine sediments. While SAV was absent at CHB for the duration of this study (1989-1992), a few small patches $\left(<1 \mathrm{~m}^{2}\right)$ of Ruppia maritima were found at $\mathrm{BI}$ in shallow water (<50 cm depth) during 1990; SAV was absent at BI in 1991 and 1992. Drift algae (Ulva sp. and Enteromorpha sp.) were occasionally present at both sites during

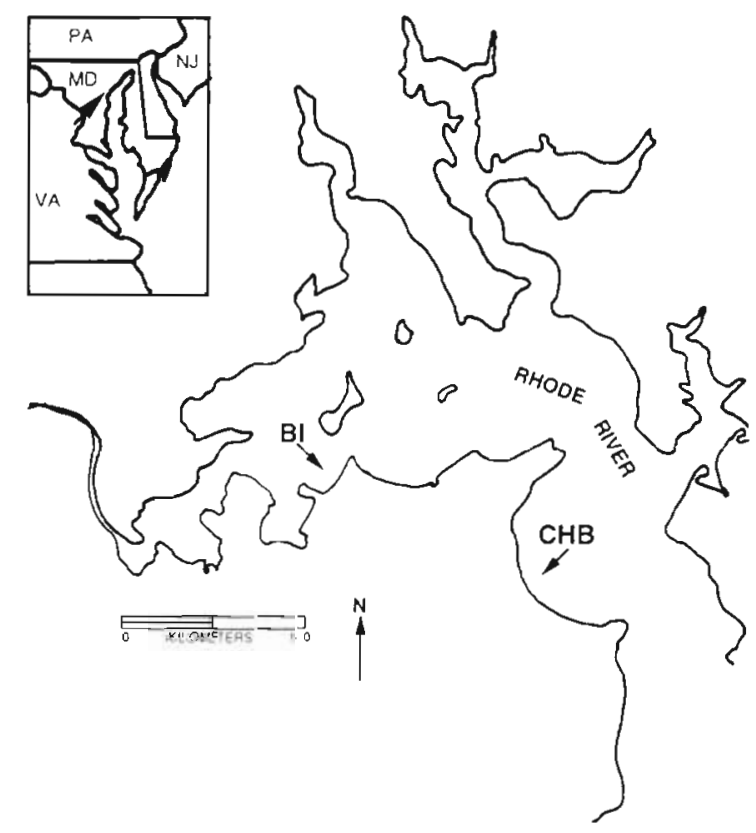

Fig. 1. Rhode River subestuary in Chesapeake Bay, Maryland, USA. Arrows indicate locations of Big Island (BI) and Canning House Bay (CHB) sites 
summer months, and small amounts of the filamentous alga Vaucheria sp. were present between January and April.

Season and time-of-day. Field samples and experiments were restricted both to the warm season (April to October) and to daylight hours, when the dominant. mainly visual, predators are active in the subestuary (Hines et al. 1987b, 1990). Thus, all work coincided with the time when predation and its effects on mobile species was likely to be greatest.

Cylinder sampling methods. Densities of epifaunal species were measured in water up to $1 \mathrm{~m}$ deep using a rigid, open-ended cylinder. The sheet-metal cylinder was suspended above water on a boom, extending over the bow of a boat, and was dropped remotely onto a sampling site by pulling a release cord. The cylinder trapped pelagic and benthic species as it fell quickly through the water column and became embedded in the bottom sediments, while still extending above the water surface (e.g. Zimmerman et al. 1984). Water within the deployed cylinder was completely pumped out, using a suction dredge with a $1 \mathrm{~mm}$ mesh bag to retain water-borne animals (e.g. Orth \& van Montfrans 1987). Animals remaining in the cylinder were removed from the sediment surface with dipnets, and the surface sediments were probed thoroughly for buried crabs. For each sample, all organisms were identified to species and counted, and a subsample ( $n>20$, when availablel was measured for size.

Influence of cylinder size on density estimates. To select the cylinder size used, we compared the effect of 4 cylinder sizes $\left(0.292,0.659,1.823\right.$, and $\left.4.674 \mathrm{~m}^{2}\right)$ on estimates of animal density. Samples were taken (as above) with alternating cylinder sizes within a narrow depth range (43 to $65 \mathrm{~cm}$ ) at $\mathrm{CHB}$, on the same date $(10$ July 1990). With the initial data, the number of samples necessary to allow a test of independence among treatments (minimum expected value of 5 ind. treatment ${ }^{-1}$; Sokal \& Rohlf 1981) was estimated for blue crabs and required more small than large cylinder samples. We adjusted sample sizes to test for cylinder-size bias in blue crabs, because our goal was to test whether such highly mobile species were able to escape cylinders below a certain size, due to the increased edge: area ratio with decreasing size. Data for all other species were also collected for comparison.

Distribution patterns at Canning House Bay. Cylinder samples were taken to examine spatial and temporal (seasonal, annual) variation in abundance of common epibenthic species at CHB. Sampling compared abundances of epibenthic fish and crustaceans as a function of water depth within shallow waters (<1 $\mathrm{m}$ depth and within $30 \mathrm{~m}$ of shore), using replicate cylinder samples $\left(1.82 \mathrm{~m}^{2}\right)$, in each of 4 years: 1989 (July-August, October): 1990 (April, May, July,
August, October); 1991 (June, July, August); and 1992 (July, August). Samples were taken from depth zones (or strata), parallel to a shoreline approximately $1 \mathrm{~km}$ long. Sampling occurred haphazardly at all tidal levels, except that unusually high tides were avoided. Water depth was measured for each sample and used to define depth zones 1 to 3 (water depths of 1-35, $36-70$, and $71-95 \mathrm{~cm}$ respectively). All samples for the 2 deepest zones were taken with a boat as described above. Samples in the shallow zone, within $2 \mathrm{~m}$ of shore, were often taken by manually tossing the cylinder from shore. On all dates, samples were taken in an alternating manner among depth zones.

The number of sample dates for each year, and the sample size within each depth zone by date, was variable. For 1990, samples were taken on 5 separate dates, over a 6 mo period, to provide seasonal information. Throughout our study, 4 to 12 replicate samples were taken for each date and zone, except in April 1990, when few animals were present and $<4$ samples were taken for each zone.

Using the data from cylinder samples, relative abundances of common species were compared among depth zones. The frequent lack of homogenous variances, and absence of any variance at all for some dates and zones, violated assumptions necessary for comparison of densities by depth zone and time using parametric statistics (Sokal \& Rohlf 1981) Instead, the proportional abundances of species among the 3 depth zones were calculated for each sample date and compared using Friedman ANOVAs and multiple comparisons (Siegel \& Castellan 1988). Only dates for which a species was present were included in the analyses.

To portray temporal variation in abundance of common species, density ( \pm SE) in the zone of highest abundance and unweighted means across all 3 zones are shown for each sample date. We performed no formal comparisons of abundance by time (season or year), or time $x$ depth, because the data did not satisfy necessary assumptions for parametric statistics (as above).

Size distributions (all 3 depth zones combined) are presented for common epibenthic species, and, for many of these species, size composition was compared as a function of depth. For these purposes, data from all sampling dates were pooled, and each population was divided into 2 size classes. Size classes were chosen to separate young-of-the-year from older individuals or immature from sexually mature individuals based upon data from Chesapeake Bay (Schwartz 1965. Haefner 1976, Williams 1984, Hines et al. 1990, Ruiz \& Hines unpubl. data). For species that were relatively rare in the 2 deepest zones (Palaemonetes pugio, Crangon septemspinosa, Fundulus heteroclitus and $F$. majalis), the shallow zone was subdivided into 2 equal 
subzones $(1-18,19-35 \mathrm{~cm})$ to provide better resolution in comparing sizes by depth. In addition, for 6 species, the 2 deepest zones were combined to provide an adequate sample size for statistical comparisons among zones. All distributions were compared using $\chi^{2}$ analyses for each species by depth.

Distribution patterns at Big Island. Cylinder samples $\left(1.82 \mathrm{~m}^{2}\right)$ were also taken at $\mathrm{BI}$ to examine the generality of abundance patterns at CHB. In August 1990, replicate samples $(n>5)$ were taken from each of 3 depth zones $(1-35,36-70$, and $71-95 \mathrm{~cm})$ in an identical fashion to those at $\mathrm{CHB}$. During sampling, small patches of Ruppia maritima were discovered and sampled in the shallow and mid depth zones ( $n=3$ for each), allowing comparison with adjacent non-vegetated substrate. For common species, abundances were compared among depth zones (non-vegetated areas) using $\chi^{2}$ tests. The overall effect of vegetation on abundance was compared with a sign test, and the effect of depth and vegetation was compared for grass shrimp abundance using a 2-way ANOVA and t-tests.

Abundance of large predators. An otter trawl $(3 \mathrm{~m}$ wide mouth, $5 \mathrm{~cm}$ mesh net body, $7 \mathrm{~mm}$ mesh cod end, and tickler chain) was used to estimate abundance of large fish and crustaceans at the CHB site, providing a measure that is independent of the cylinder samples and more likely to include rare species (because of an increase in area sampled relative to cylinder samples). Replicate ( 2 to 6 ) trawl samples were taken approximately monthly, within a week of cylinder sampling dates for 1990 and 1991. Trawl samples for each monthly period always included 2 sites adjacent to the area used for cylinder sampling; replicate samples were taken from these sites on 1. (May and November 1990 ) or 3 (all other dates) consecutive days. The trawl samples, taken perpendicular to shore, included a depth range from 0 to $\mathrm{ca} 100 \mathrm{~cm}$. The trawl net was positioned on shore, to begin fishing immediately, and hauled $32 \mathrm{~m}$ offshore. The trawls sampled an approximate area of $96 \mathrm{~m}^{2}$, but the exact area and depth range varied among trawls according to tidal conditions at the time of sampling. For each trawl, the catch was identified to species and counted, and a subsample ( $n=20$ when available) was measured to the nearest $\mathrm{mm}$.

Risk of predalion. We used tethering to compare the relative risks of predation among depth zones for grass shrimp, mummichogs, and blue crabs at CHB. This technique has been a valuable experimental approach to assess predation pressure in the field for crabs, lobsters, fish, and snails (e.g. Heck \& Thoman 1981. Watanabe 1984, McIvor \& Odum 1988, Rozas \& Odum 1988, Wilson et al. 1987). While tethering can significantly alter animal behavior and absolute rates of predation (e.g. Barshaw \& Able 1990b, Smith 1990), it allows comparison of relative rates among experimental sites by controlling presumably for the effects of tethering.

In June 1991, tethered grass shrimp and mummichogs were placed in all 3 depth zones at CHB. Animals were collected the day of experiments and brought into the laboratory to attach tethers. For grass shrimp, monofilament line $(0.45 \mathrm{~kg}$ test, $0.08 \mathrm{~mm}$ diameter) was tied around the abdomen, anterior to the first pleopods; this halter was then tied to a leader of $2.72 \mathrm{~kg}$ test monofilament. For mummichogs, a needle with attached nylon suture $(0.017 \mathrm{~mm}$ diameter $)$ was pushed through the epidermis and connective tissue just anterior to the dorsal fin; after removing the needle, the thread was tied into a loop that ran through the fish. Each tethered grass shrimp and mummichogs was tied individually (on a $20 \mathrm{~cm}$ line) to the end of a $50 \mathrm{~cm}$ steel rod buried horizontally in the sediment.

We used blue crabs in a similar tether experiment, including all 3 depth zones, at CHB in August 1989. A loop of monofilament $(9.07 \mathrm{~kg}$ test) was tied around the crabs' antero-lateral spines to form a halter, which was tied to a coated steel leader $(4.54 \mathrm{~kg}$ test; e.g. Smith 1990). The blue crabs were tethered individually (by a 0.75 to $1.00 \mathrm{~m} \mathrm{line)}$ to a steel spike pushed vertically beneath the sediment.

To control for differences in predation risk due to size, only a narrow size range was used in experiments for shrimp (30 to $35 \mathrm{~mm}$ ), mummichogs ( 40 to $50 \mathrm{~mm}$ ), and blue crabs ( 30 to $70 \mathrm{~mm}$ ). Shrimp and blue crabs were further restricted to intermolt individuals, to reduce any variation in behavior and predation risk due to molt stage.

For each species, tether experiments were run on multiple days, and within a period of 3 to $4 \mathrm{~d}$, with all depth zones represented on each day. Within a depth zone, distance between tethered animals $(2 \mathrm{~m})$ prevented interactions among individuals. Based upon initial results, experiments with shrimp were run for $30 \mathrm{~min}$, those with mummichogs were run for $90 \mathrm{~min}$, and blue crab tethering experiments lasted $24 \mathrm{~h}$. All individuals were scored as either live or eaten, based upon presence or absence respectively.

Our laboratory observations indicated that tethered animals (controls) did not escape their tethers and maintained apparently normal behavior, surviving the experimental period in the absence of predation. Despite prey ability to move quickly and perform escape behaviors within the confines of a tether, mortality rates of tethered animals were consistently higher than untethered animals when exposed to several predator species in the laboratory (Hines \& Ruiz unpubl. dataj. Not surprisingly, predator species differed significantly in their consumption rates of both tethered and untethered prey in these preliminary experi- 
Table 1. Fish and crustacean species caught in cylinder and trawl samples at CHB. Animals are grouped by relative abundance (see text for explanation). Means ( \pm SE) of each species are shown for trawl samples $(n=52)$; - : species not sampled quantatitively by trawls, due to small size of individual animals. For cylinder samples ( $\mathrm{n}=243$ ), abundance is shown as the mean ( \pm SE) of unweighted means for all 3 depth zones on each sample date $(n=13)$

\begin{tabular}{|c|c|c|}
\hline Sample type: & $\begin{array}{c}\text { Cylinder } \\
\text { Mean abundance (SE) }\end{array}$ & $\begin{array}{l}\text { Trawl } \\
\text { Mean abundance (SE) }\end{array}$ \\
\hline \multicolumn{3}{|l|}{ Common species } \\
\hline Anchoa mitchelli bay anchovy & $1.671(0.772)$ & $0.173(0.071)$ \\
\hline Apeltes quadracus four-spine stickleback & $1.297(0.881)$ & $0.462(0.222)$ \\
\hline Callinectes sapidus blue crab & $0.396(0.057)$ & $7.154(0.866)$ \\
\hline Crangon septemspinosa sand shrimp & $4.325(2.228)$ & $-\quad-$ \\
\hline Fundulus heterociltus mummichog & $0.331(0.101)$ & $1.981(0.605)$ \\
\hline Fundulus majalis banded killifish & $0.248(0.086)$ & $0.885\{0.270\}$ \\
\hline Gobiesox strumosus skilletfish & $0.125(0.077)$ & $0.000(0.000)$ \\
\hline Gobisoma bosci naked goby & $0.181(0.084)$ & $0.019(0.019)$ \\
\hline Leiostomus xanthurus spot & $0.429(0.341)$ & $12.038(4.909)$ \\
\hline Menidia menidia Atlantic silverside & $1.601(0.396)$ & $0.423(0.251)$ \\
\hline Micropogonias undulatus Atlantic croaker & $0.020(0.013)$ & $1.115(0.330)$ \\
\hline Palaemonetes pugio grass shrimp & $3.840(1.350)$ & $-\quad-$ \\
\hline Rhithropanopeus harrisii mudcrab & $0.447(0.203)$ & - \\
\hline \multicolumn{3}{|l|}{ Rare species } \\
\hline Anguilla rostrata American eel & $0.038(0.023)$ & $0.000(0.000)$ \\
\hline Brevoortia tyrannus Atlantic menhadden & $0.004(0.004)$ & $0.308(0.308)$ \\
\hline Chasmodes bosquianus striped blenny & $0.000(0.000)$ & $0.000(0.000)$ \\
\hline Cyprinodon variegatus sheepshead minnow & $0.006(0.004)$ & $0.038(0.038)$ \\
\hline Limulus polyphemus horseshoe crab & $0.020(0.013)$ & $0.038(0.038)$ \\
\hline Lucania parva rainwater killifish & $0.004(0.004)$ & $0.000(0.000)$ \\
\hline Microgobias thalassinus green goby & $0.030(0.024)$ & $0.000(0.000)$ \\
\hline Morone saxatilis striped bass & $0.000(0.000)$ & $0.000(0.000)$ \\
\hline Paralichthys dentatus summer flounder & $0.005(0.005)$ & $0.019(0.019)$ \\
\hline Pseudopleuronectes americanus winter flounder & $0.000(0.000)$ & $0.038(0.027)$ \\
\hline Sygnathus fuscus northern pipefish & $0.106(0.033)$ & $0.019(0.019)$ \\
\hline Synodus foetens inshore lizardfish & $0.005(0.005)$ & $0.000(0.000)$ \\
\hline Trinectes maculatus hogchocker & $0.015(0.010)$ & $0.154(0.004)$ \\
\hline
\end{tabular}

ments. Thus, experimental results must be interpreted cautiously, because tethering may differentially affect vulnerability to various predators, which could change among depth zones

\section{RESULTS}

Cylinder and trawl samples in the nearshore waters of the Rhode River subestuary contained 26 species, which we categorized into 2 groups: 13 common species and 13 rare species (Table 1). The distinction between common and rare species depended on whether mean abundance for any depth zone was greater or less than 1.0 ind. cylinder ${ }^{-1}$ on any sampling date. With the exception of Atlantic croaker, which exhibits extreme temporal variation in abundance and can be very abundant (below; see also Hines 1990), a similar classification would result from using total mean abundance across all dates and depths (Table 1). For both $\mathrm{CHB}$ and $\mathrm{BI}$, distributional patterns were examined in detail for only common species, because rare species did not provide adequate data for further analysis.

\section{Influence of cylinder size on density estimates}

Cylinder size had a significant effect on density estimates for the four-spine stickleback Apeltes quadracus $\left(\chi^{2}=56.95\right.$, df $\left.=2, p<0.001\right)$ and, when data for the 2 smallest cylinders were pooled, the blue crab Callinectes sapidus $\left(\chi^{2}=5.69, \mathrm{df}=1, \mathrm{p}<0.05\right.$; Fig. 2). For both species, density increased 2 - or 3 -fold from the 2 smallest cylinders to the second largest cylinder $\left(1.82 \mathrm{~m}^{2}\right)$, with no further increase when using the largest cylinder. Although other species were captured in these cylinder samples, abundances were inadequate (i.e. lacked an expected value of $\geq 5$ cell $^{-1}$ necessary for chi-square analysis) to test for significant differences among treatments.

Based upon these comparisons, the second largest cylinder $\left(1.82 \mathrm{~m}^{2}\right)$ was used as a standard sampling 


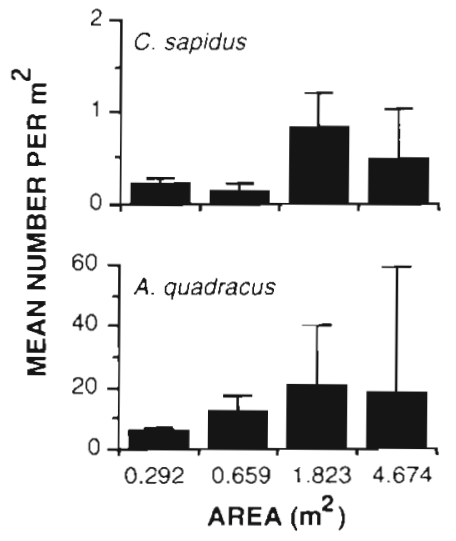

Fig. 2. Callinectes sapidus and Apeltes quadracus. Effect of cylinder size on density estimates at CHB. Density estimates (mean $\pm \mathrm{SE}$ ) are shown for samples taken with each of 4 different cylinder sizes (area $\left.=0.292,0.659,1.823,4.674 \mathrm{~m}^{2}\right)$; no. of samples for each cylinder size are 16,11,8 and 8 respectively unit. The 2 smallest cylinders underestimated abundance of highly mobile species, and use of the largest cylinder did not increase density estimates beyond those measured with the $1.82 \mathrm{~m}^{2}$ cylinder.

\section{Distribution patterns at Canning House Bay}

\section{Abundance}

The relative abundance for 9 of the 13 common species differed significantly among depth zones in the nearshore shallows (Fig. 3, Table 2). The results of multiple comparison tests were used to classify species according to 3 patterns of depth zonation. Shallow zone species, which had highest relative abundances in the shallow zone and significantly lower abundances in the mid and deep zones, included Palaemonetes pugio, Crangon septemspinosa, Fun-

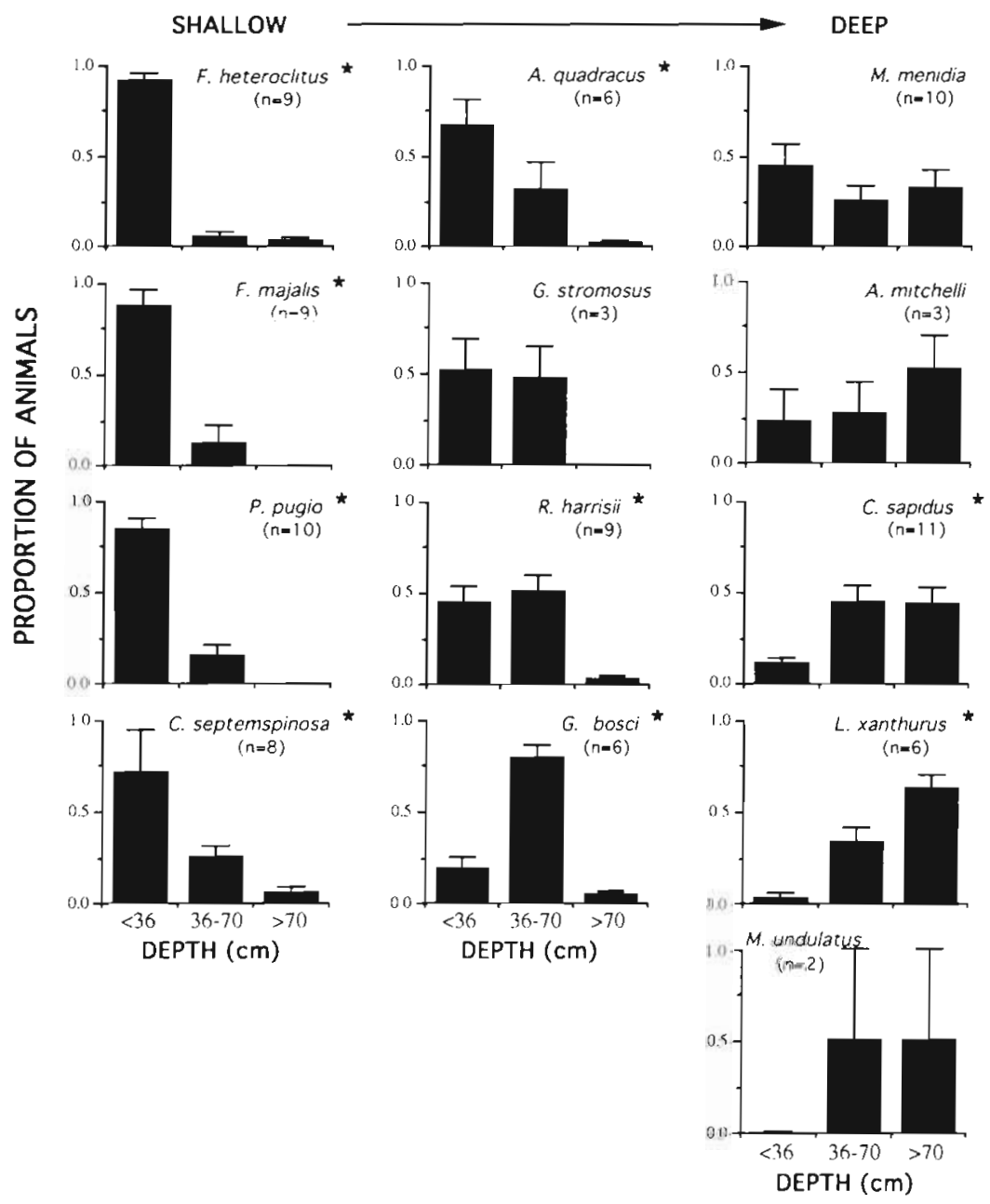

Fig. 3. Comparison of proportional abundance among 3 depth zones for common species (see Table 1) at CHB. Shown for each species is the proportional abundance (mean \pm SE) among the 3 zones; data include only those sample periods ( $n$ ) when the respective species was present. Species are arranged according to relative abundance in shallow to deep water; "significant differences among depth zones 
Table 2. Classification of common species based upon distribution among 3 depth zones at CHB. Shown are results of Friedman 2-way ANOVAs $\left(F_{r}\right.$ with number of depth zones $k$ and sample dates $\left.N\right)$ which compare proportional abundance among depth zones (as shown in Fig. 3) for each species; zones not underscored by a continuous line are significantly different $(\mathrm{p}<0.05)$ based on multiple comparisons. Species are classified into 3 groups (shallow, mid, and deep zone species) according to outcome of comparisons, and unclassified species showed no significant differences (ns) in abundance among depth zones. $\mathrm{df}=2$ for all comparisons

\begin{tabular}{|c|c|c|c|c|}
\hline & $F_{r}$ & $k, N$ & $\mathrm{p}$ & Comparisons \\
\hline \multicolumn{5}{|l|}{ Shallow zone species } \\
\hline Crangon septemspinosa & 11.45 & 3,10 & $<0.01$ & 123 \\
\hline Fundulus heteroclitus & 11.45 & 3,10 & $<0.01$ & $1 \underline{23}$ \\
\hline Fundulus majalis & 10.71 & 3,10 & $<0.01$ & 123 \\
\hline Palaemonetes pugio & 18.03 & 3.12 & $<0.01$ & $1 \underline{23}$ \\
\hline \multicolumn{5}{|l|}{ Mid zone species } \\
\hline Apeltes quadracus & 9.25 & 3,6 & $<0.01$ & 123 \\
\hline Gobisoma bosci & 17.39 & 3,7 & $<0.01$ & 123 \\
\hline Rhithropanopeus harrisii & i 11.23 & 3,11 & $<0.01$ & 123 \\
\hline \multicolumn{5}{|l|}{ Deep zone species } \\
\hline Callinectes sapidus & 10.84 & 3,12 & $<0.01$ & 123 \\
\hline Leiostomus xanthurus & 8.33 & 3,6 & $<0.05$ & 123 \\
\hline \multicolumn{5}{|l|}{ Unclassified species } \\
\hline Anchoa mitchelli & 1.20 & 3,5 & ns & \\
\hline Gobiesox strumosus & 4.67 & 3,3 & ns & \\
\hline Menidia menidia & 0.95 & 3,10 & ns & \\
\hline
\end{tabular}

$\mathrm{df}=1, \mathrm{p}<0.01$ ) and a pairwise difference (Tukey HSD, $p<0.05$ ) between the shallow zone and other 2 zones.

The distribution patterns for 4 of the common species were not classified by our statistical analyses (Table 2). Although Gobiesox strumosus and Micropogonias undulatus were almost completely absent from the deep and shallow zones respectively (Fig. 3), the small sample size and low statistical power for each could not detect significant differences among zones that probably existed. In contrast, no zonation was evident either graphically or statistically for Menidia menidia and Anchoa mitchelli.

The common species at CHB exhibited strong temporal variation in their overall abundances across all 3 zones and at the zone of highest density (Fig. 4). Temporal patterns were not analyzed formally, because the absence of most species on some dates (and frequent heterogeneous variances) prohibited the use of many common statistical procedures. Instead, we chose to simply display the variation in abundance among sample dates over the 4 yr period of study. From these data we draw 2 main conclusions. First, in examining the data for 1990, there is evidence of a seasonal interaction in the zonation pattern

dulus heteroclitus, and F. majalis (Fig. 3, Table 2). Relative to shallow zone species, the $3 \mathrm{mid}$ zone species (Apeltes quadracus, Gobiosoma bosci, and Rhithropanopeus harrisii) exhibited a shift in relative abundance toward deeper water; their peak abundances were in either shallow or mid zones, and they still were rare in the deep zone. The relative abundances of all 3 species differed significantly among depth zones, but multiple comparisons showed significant differences (from mid to deep zones) for only $G$. bosci and $R$. harrisii (Table 2). Nevertheless, A. quadracus was classified as a mid zone species, because it was rare in the deep zone and exhibited an overall statistically significant difference in its distribution among zones. Finally, Callinectes sapidus and Leiostomus xanthurus were classified as deep zone species, displaying overall significant differences in relative abundances among zones with proportionally few individuals in the shallow zone (Fig. 3, Table 2). Multiple comparisons revealed a significant difference between shallow and deep zones for L. xanthurus and no significant differences for $C$. sapidus. However, unlike $A$. quadracus and other species, the data for $C$. sapidus were not heteroscedastic (Bartlett's test, $p>0.05$ ) and allowed further analysis with a 1-way ANOVA, which revealed an overall significant difference $(F=5.445$, described above. Shallow and mid zone species were absent in April 1990, and some of these species were not detected until July or August. When present, these species showed a strong pattern of depth zonation (Fig. 3). By contrast, blue crabs and spot were present in April samples, and the latter was not detected in August and October. Second, year-to-year changes occurred in the species composition of this community and abundance of species present. This annual variation was most extreme for Atlantic croaker and skilletfish, which were only present in cylinder samples for 2 or 3 dates, respectively, out of the entire 13 sampling dates. Data from trawl samples (below) provide a better measure of the large year-to-year variation in croaker abundance (see also Hines et al. 1990).

Size

Size-frequency distributions of the common species from cylinder samples at $\mathrm{CHB}$ indicate a fundamental difference in sizes of organisms by depth. Interspecifically, the deep zone species (and also Micropogonias undulatus, which was unclassified but never occurred in the shallow zone) were represented by more large individuals than shallow and mid zone spe- 


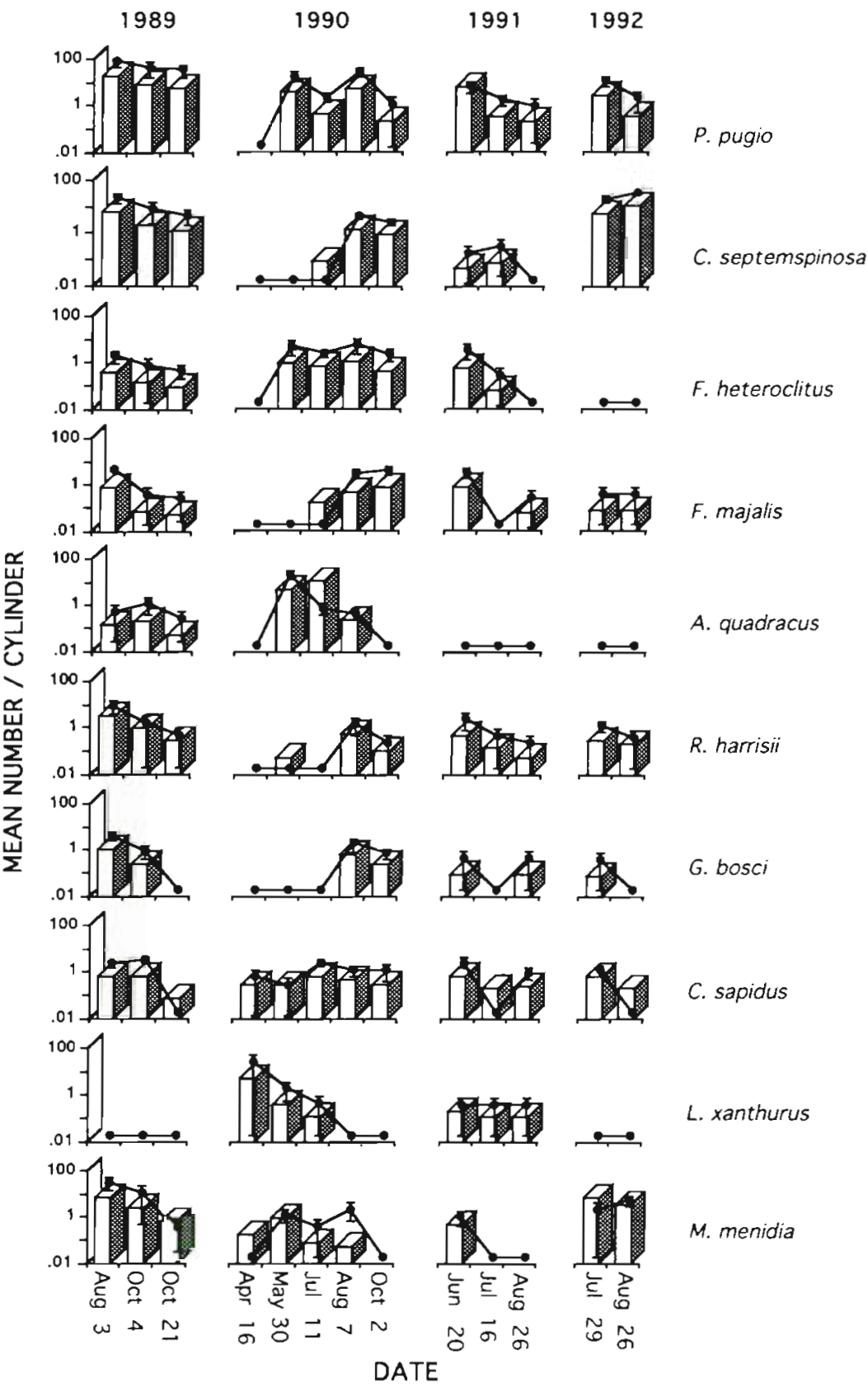

Fig. 4. Temporal variation in abundance of shallow, mid, and deep zone species (see Table 1) at CHB. Average abundances across all depth zones (= unweighted means) are shown with histograms, and abundances (means $\pm \mathrm{SE}$ ) at zone of peak abundance are depicted by $(\bullet)$. Mean values are plotted on a log scale for each sample perıod during 4 yr (1989-1992)
(Fig. 5, Table 4); the exception was Crangon septemspinosa, for which size composition did not differ with depth. Such intraspecific size comparisons were not made for some of the common species, because they lacked: sufficient sample sizes (Gobiesox strumosus, Micropogonias undulatus); dispersion among zones (Gobisoma bosci); or more than one age/size class (Anchoa mitchelli, Leiostomus xanthurus).

\section{Distribution patterns at Big Island}

The relative abundance of species among depth zones for non-vegetated areas at $\mathrm{BI}$ was similar to that observed at CHB. As at CHB, grass shrimp and both Fundulus species had their peak densities in the shallowest zone, departing significantly from uniform distributions (shrimp: $\chi^{2}=56.40, \mathrm{df}=1, \mathrm{p}$ $<0.001$, mummichogs: $\chi^{2}=12.28$, df $=$ 1, $\mathrm{p}<0.01$; banded killifish: $\chi^{2}=12.95$, $\mathrm{df}=1, \mathrm{p}<0.01)$. Other species at $\mathrm{BI}$ were not abundant enough in cylinder samples for statistical analyses, but their patterns of distribution appeared similar to those at $\mathrm{CHB}$. In particular, blue crabs were most abundant in the deep zone, and four-spine sticklebacks were present in all zones and most abundant in the mid zone.

Each of the common species had a higher abundance in SAV compared to non-vegetated habitat of the same depth zone (Fig 6). Treating each zone $x$ species combination as an independent paired sample, all 14 of the pairs had their highest abundance in SAV, representing a highly significant difference among habitats (Sign Test after Snedecor \& Cochran 1978: $\chi^{2}=$ 12.07, $\mathrm{df}=1, \mathrm{p}<0.001$ ) Moreover, the decline seen with increasing depth for non-vegetated habitat appeared to be cies, showing a tendency for the largest species to occur in the deepest zone (Table 3). Intraspecifically, the relative abundance of large (i.e. mature or $1+y \mathrm{r}$ class) individuals increased significantly with increasing depth for Palaemonetes pugio, Fundulus heteroclitus, F. majalis, Rhithropanopeus harrisii, Apeltés quadracus, Menidia menidia, and Callinectes sapidus reversed or diminished for all of these species (Fig. 6) This interaction appeared most pronounced for Palaemonetes pugio. A 2-way ANOVA revealed a significant effect of vegetation and the interaction of vegetation $x$ depth on abundance, and $t$-tests found a significant effect of vegetation in both zones and of depth for only non-vegetated habitat (Table 5). 


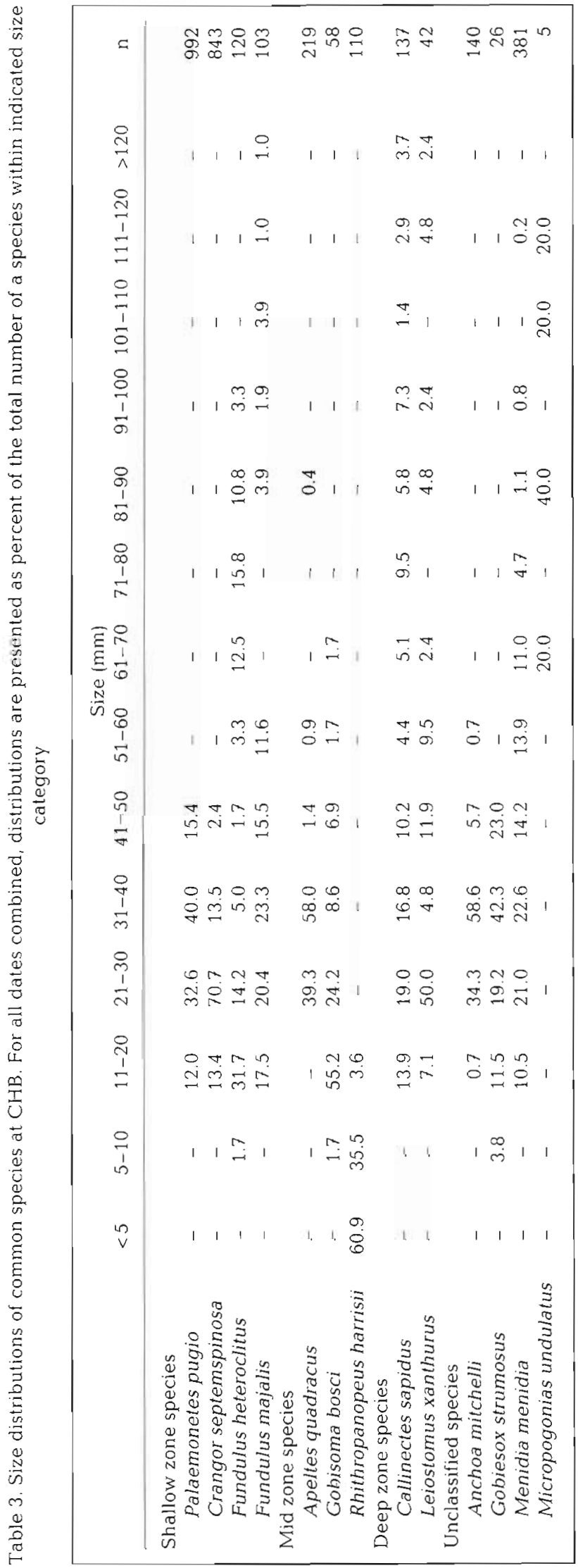

Similar to $\mathrm{CHB}$, an apparent increase in size occurred with depth for 3 of the common shallow zone species (Palaemonetes pugio, Fundulus heteroclitus and F. majalis). Statistical comparison of these patterns is complicated by the low abundance at particular depth subzones, or for particular size groups (creating expected values below the recommended level of 5; Sokal \& Rohlf 1981). To allow comparisons, depth subzones were combined for $P$. pugio, and a significant difference existed when comparing the size structure between the shallowest subzone $(0-18 \mathrm{~cm})$ and deeper water $\left(\chi^{2}=56.14, \mathrm{df}=2, \mathrm{p}<0.001\right)$. For both Fundulus species combined, size structure was also significantly different among the 3 zones $\left(\chi^{2}=32.56\right.$, $\mathrm{df}=2, \mathrm{p}<0.001$ )

\section{Abundance of large predators}

Trawl samples at CHB were composed of 16 species (Table 1), which exhibited seasonal and annual variation in abundance and mean size (Fig. 7). The most abundant species included Fundulus heteroclitus, F. majalis, Leiostomus xanthurus, and Callinectes sapidus, and all of these were present from May to October. During the summer, abundance of the first 3 declined, while abundance of blue crabs remained relatively stable. Trinectes maculatus, Pseudopleuronectes americanus and Paralichtys dentatus were least abundant and often absent in monthly trawl samples. Micropogonias undulatus exhibited the highest interannual variation, being absent in trawl and cylinder samples for 3 yr $(1989,1990,1992)$ and present in all monthly samples for 1991

For 3 of the most common fish species (Fundulus majalis, Leiostomus xanthurus and Micropogonias undulatus), trawl samples early in the season contained relatively small individuals compared to mid-late summer (Fig 7). Both the F. heteroclitus and Callinectes sapidus populations exhibited little directional change in mean size from May to October; however, the latter decreased in size in November, when new recruitment occurred and larger crabs may have moved out of the subestuary (e.g. Hines et al. 1987b, 1990).

Overall, estimates of species composition and relative abundance of large, epibenthic predators were consistent between trawl and cylinder samples at CHB (Table 1). While a few rare species were added with trawl samples, trawl and cylinder samples both indicate that the Fundulus spp., Leiostomus xanthurus, Callinectes sapidus, and (in 1 yr) Micropogonias undulatus, due to their size and abundance, were the predators of potential importance to shallow zone species. 

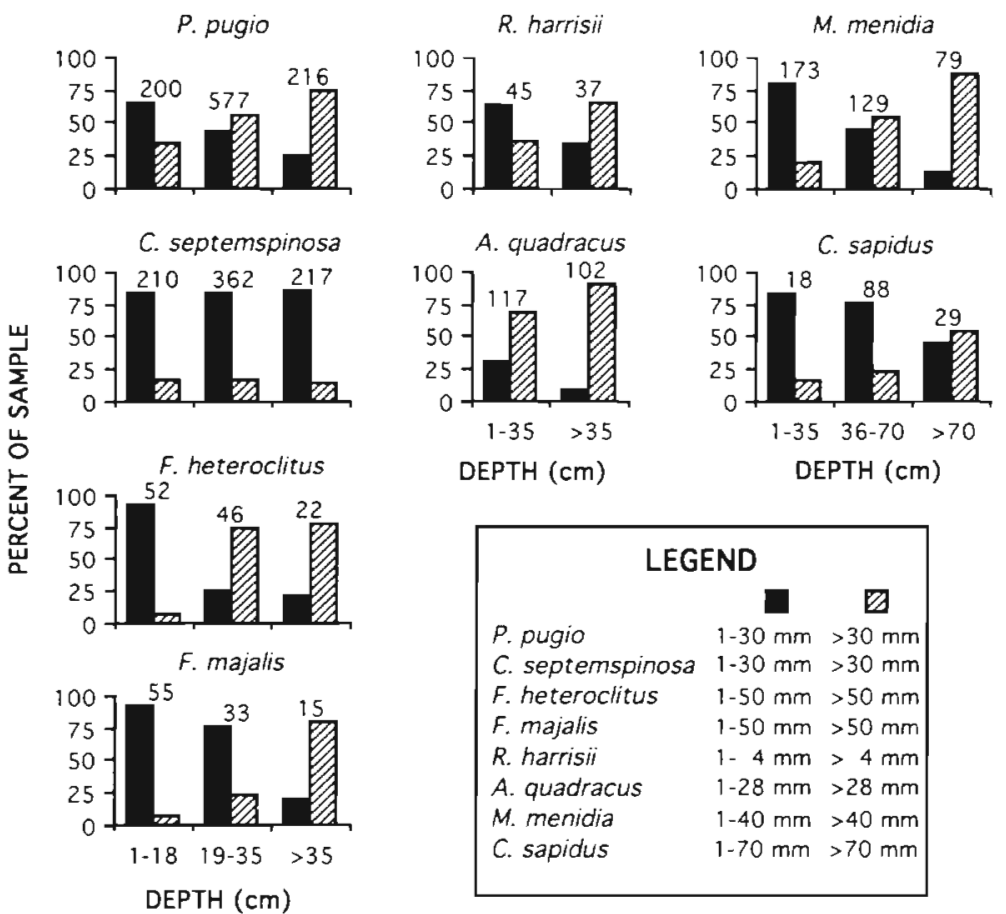

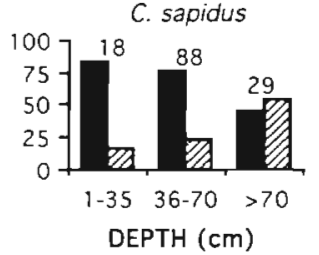

composition with depth. However, nearly all potential predators large enough to consume the tethered prey were absent from the shallowest zone, and composition of these predators did not change appreciably between the mid and deep zones (Fig. 3 . Table 2). In addition, for small intermolt blue crabs the major source ( $>90 \%$ ) of mortality in the Rhode River is cannibalistic large blue crabs, rather than a suite of species (Smith 1990). Thus, we surmise that the large differences in mortality among zones, in combination with the observed corresponding changes in predator depth distributions, support the hypothesis that shallow water provides a refuge from predation in the absence of SAV.

\section{DISCUSSION}

\section{Shallow water as refuge habitat}

Large, highly mobile fish and crustaceans are often found in the shallow, and especially intertidal, areas of estuarine habitats (e.g. Reise 1978, deVlas 1979, Peterson 1979, Peterson \& Quammen 1982, Rozas \& Hackney 1984). Many of these an-

Table 4. Comparison of size composition by depth for 8 common species at CHB. Shown are results of chi-square analyses. ns: not significant at $\mathrm{p}>0.05$

\begin{tabular}{|lrcc|}
\hline \multicolumn{1}{c}{ Species } & $\chi^{2}$ & $\mathrm{df}$ & $\mathrm{p}$ \\
\hline Palaemonetes pugio & 65.72 & 2 & $<0.001$ \\
Crangon septemspinosa & 1.19 & 2 & $\mathrm{~ns}$ \\
Fundulus heteroclitus & 53.84 & 2 & $<0.001$ \\
Fundulus majalis & 34.91 & 2 & $<0.001$ \\
Rhithropanopeus harrisii & 6.98 & 1 & $<0.01$ \\
Apeltes quadracus & 14.44 & 1 & $<0.001$ \\
Menidia menidia & 101.23 & 2 & $<0.001$ \\
\hline
\end{tabular}

\section{Risk of predation}

Survival of tethered grass shrimp, mummichogs, and small blue crabs differed significantly among depth zones: $\chi^{2}=34.37, \mathrm{df}=2, \mathrm{p}<0.001$ for Palaemonetes pugio: $\chi^{2}=17.57, \mathrm{df}=2, \mathrm{p}<0.001$ for Fundulus heteroclitus: $\chi^{2}=15.57, \mathrm{df}=2, \mathrm{p}<0.001$ for Callinectes sapidus. For each species, mortality $(>80 \%$ ) in the deepest $(60-80 \mathrm{~cm})$ zone was much greater than that $(20$ to $45 \%)$ in the shallowest $(15-20 \mathrm{~cm})$ zone. One interpretation of these experiments might be that they reflect differential effects (interaction) of tethering on vulnerability to various predator species, which may change imals maintain a relatively constant depth by moving with the ebb and flow of tides that results in inter- and intraspecific size segregation by depth (e.g. Macer 1967. Gibson 1973, Kuipers 1973, Kneib 1984b, 1987, Bishop \& Kahn 1991); these patterns are often attrib-

Table 5. Palaemonetes pugio. Comparison of grass shrimp abundance by depth and habitat type (presence or absence of SAV) at BI. Results of 2-way ANOVA (depth $\times$ habitat) and of separate $t$-tests for effects of habitat within each depth zone, and of depth within each habitat type. $\mathrm{df}=1 \mathrm{in}$ all cases; ns: not significant at $\mathrm{p}>0.05$

\begin{tabular}{|lcc|}
\hline 2-way ANOVA & F-ratio & $\mathrm{p}$ \\
Factor & 0.80 & $\mathrm{~ns}$ \\
\hline Depth & 71.88 & $<0.001$ \\
Habitat & 6.17 & $<0.05$ \\
Depth $\times$ Habitat & & \\
t-tests & $t$ & $\mathrm{p}$ \\
By habitat & 15.22 & $<0.001$ \\
\hline Depth zone 1 & 3.74 & $<0.01$ \\
Depth zone 2 & $t$ & $\mathrm{p}$ \\
By depth zone & 1.64 & $\mathrm{~ns}$ \\
\hline SAV present & 2.99 & $<0.01$ \\
SAV absent & & \\
\hline
\end{tabular}



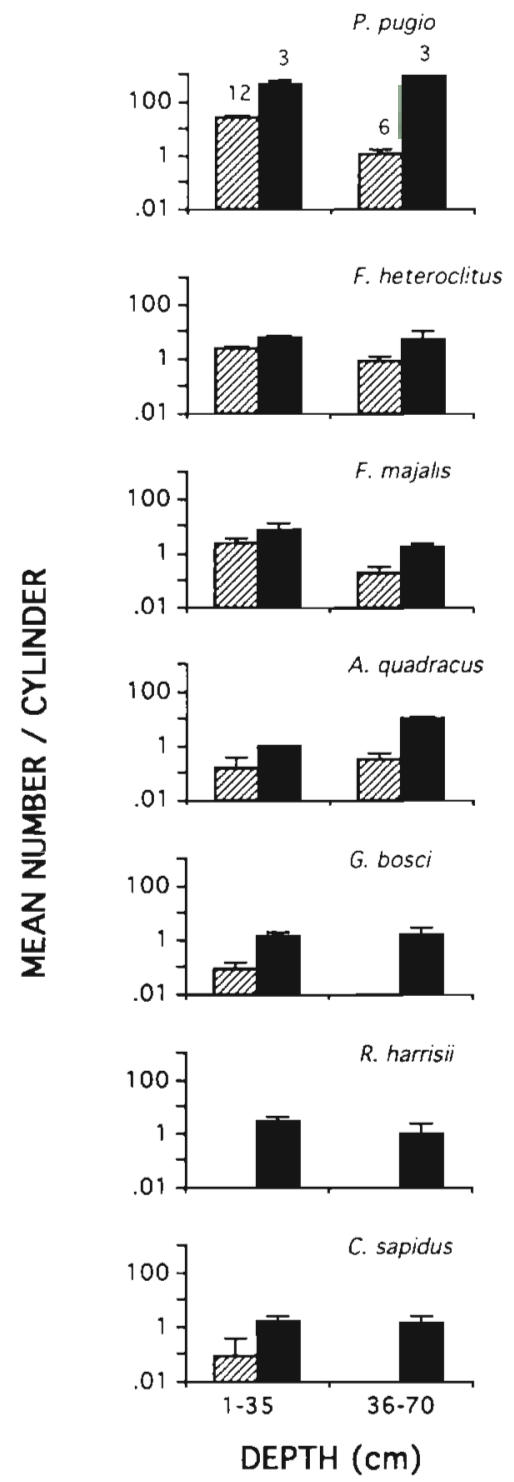

Fig. 6. Comparison of densities by depth and substrate for common species (see Table 1) at BI, August 1990. In the presence (solid histograms) and absence (diagonally shaded histograms) of SAV, mean density $\pm \mathrm{SE}$ is shown by depth zone for

each species; no. of cylinder samples are indicated at top

uted to depth- and size-dependent differences in the risk of predation (e.g. Boesch \& Turner 1984, Rozas \& Odum 1987b, c, Mclvor \& Odum 1988, Gibson 1986). In particular, risk of predation in shallow water estuaries is thought to diminish with both decreasing water depth and increasing individual size. As a result, larger individuals should experience a greater refuge in size from predators than smaller individuals, allowing the largest animals to exploit depths that are too risky for smaller ones.

Strong support for this model of depth- and sizedependent risk of predation exists for some benthic
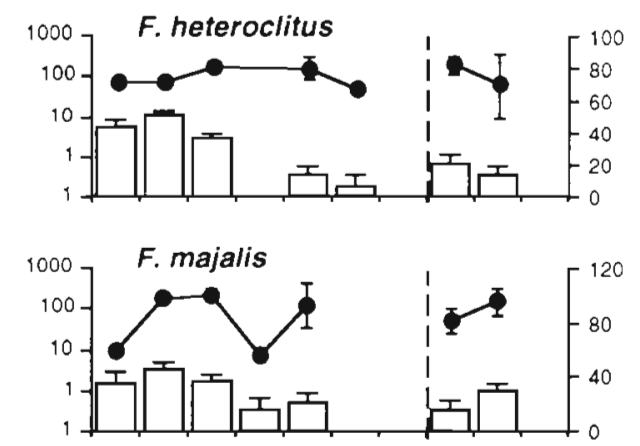

๑P. americanus
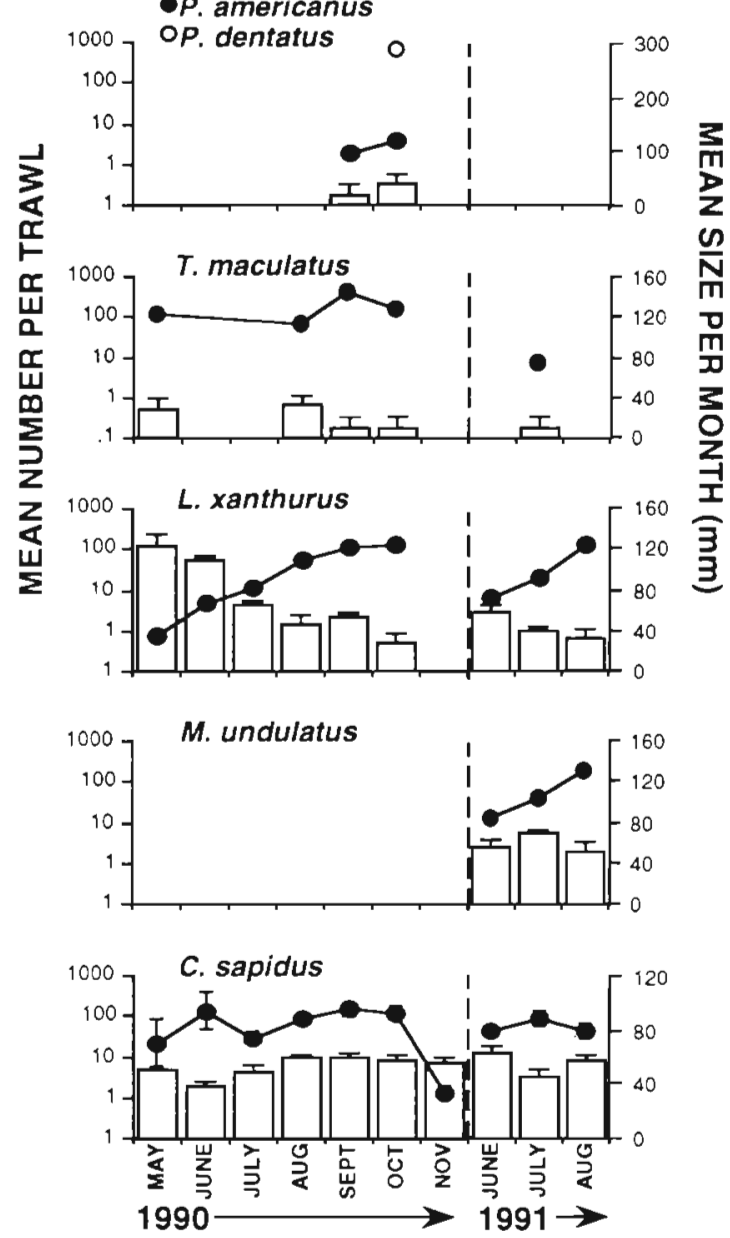

Fig. 7 Seasonal and annual variation in abundance and size for large epibenthic species (see Table 1) in shallow water trawl samples at $\mathrm{CHB}$. Mean abundance \pm SE (histograms; 2 trawls for May and November, and 6 trawls per other sample dates $)$ and mean size $\pm \mathrm{SE}(\cdot ;$ sample size varies according

to availability) is shown for each sample date by species

marine invertebrates on rocky shores (e.g. Connell 1972, Underwood 1979) and fish in freshwater habitats (e.g. Fraser \& Emmons 1984, Power et al. 1985, Schlosser 1987, 1988a, b, Harvey et al. 1988, Werner \& Hall 1988, Harvey 1991)(see also review by Lima \& Dill 1990 on predation risk and prey behavior). For estua- 

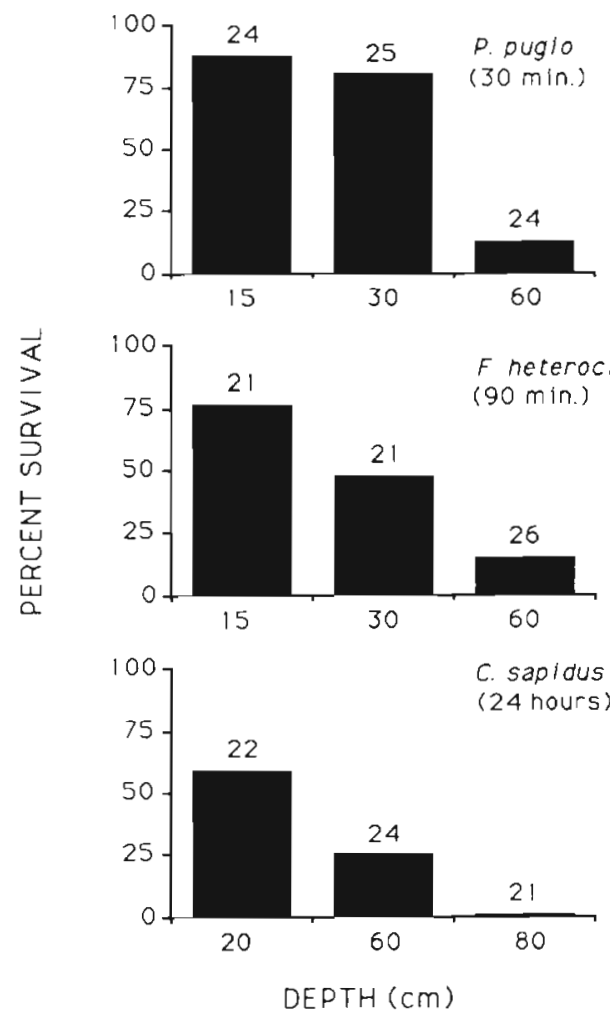

Fig. 8. Palaemonetes pugio, Fundulus heteroclitus, and $F$. majalis. Depth-specific survival of tethered grass shrimp $(30$ min), small mummichogs (90 min), and small blue crabs (24 h) at $\mathrm{CHB}$. For grass shrimp and mummichogs, percent survival of tethered animals is shown at 15,30 , and $60 \mathrm{~cm}$ depths (June 1991); survival of blue crabs is shown at 10,60 , and $80 \mathrm{~cm}$ depths (August 1989). Sample sizes shown at top of each histogram

rine habitats, predation risk decreases for snails and mangrove crabs with increasing vertical height (i.e. decreasing depth and duration of submersionj on emergent vegetation (Hamilton 1976, Vaughn \& Fisher 1988, Wilson 1989). In addition, Mclvor \& Odum (1988) found that risk of predation for Fundulus heteroclitus was less at a shallow site with SAV compared to a deeper, non-vegetated site. However, hypotheses about the independent effect of depth on predation risk have not been tested experimentally in the field for estuarine epifaunal communities.

The strong depth- and size-related distribution patterns observed for fish and crustaceans at CHB and BI appear to exist in other areas of the Rhode River, and in estuaries of Virginia and North Carolina. In censusing local grass shrimp abundance by depth at multiple sites along the Rhode River (Ruiz \& Everett unpubl. data), we have routinely found strong depth zonation in summer months that is consistent with data presented in this study. Over the past $12 \mathrm{yr}$, monthly trawls and frequent underwater observations further indicate that grass shrimp and small killifish (Fundulus spp.) were consistently rare in deep ( 2 to $4 \mathrm{~m}$ ) portions of the Rhode River (Hines unpubl. data). Similar depthrestricted distributions exist for grass shrimp and small killifish in non-vegetated portions of North Carolina estuaries (Townsend 1991, Innis 1992). Finally, in a 1992 survey of non-vegetated habitat at the confluence of Virginia's York and Mattaponi Rivers, densities of grass shrimp and small $(<35 \mathrm{~mm})$ blue crabs also exhibited similar differences by depth (R. Everett, U.S. Fish \& Wildlife Service, pers. comm.).

The refuge provided for grass shrimp, small killifish, and small blue crabs by shallow water most likely resulted from differences in the abundance of predators and, perhaps, the ability of predators to capture prey among depth zones. Spot, croaker, blue crabs, and large ( $>60 \mathrm{~mm}$ ) mummichogs are known predators of grass shrimp and small killifish (Schmelz 1964, Nixon \& Oviatt 1973, Heck \& Thoman 1981, Kneib 1982, West \& Williams 1986, Fitz 1990, Posey \& Hines 1991, Everett \& Ruiz 1993) that were commonly present during this study. Cannibalistic blue crabs are the major predator of other blue crabs in the Rhode River (Smith 1990, Hines \& Ruiz unpubl. data). All of these predator species were least abundant in the shallow zone. Avoidance of the shallow zone by predators may result from increased risk from avian and mammalian predators, decreased foraging ability, or increased physiological stress due to elevated temperature or reduced oxygen levels relative to deeper water (e.g. Jenni 1969, Valiela et al. 1977, Gibson 1982, 1986, Kneib 1982, Rozas \& Hackney 1984, Rozas \& Odum 1987b), but the underlying mechanisms which generate these predator distributions are unclear.

Although the observed distributions of grass shrimp and small killifish may result from the simultaneous influence of many factors (e.g. variation in food availability, sediment characteristics, oxygen, and temperature), their selection of shallow zone habitat appears driven primarily by its refuge value. This is supported by observations of diurnal and seasonal variation in distributions at the Rhode River. First, grass shrimp disperse out of the shallow zone at night (Ruiz unpubl. data), suggesting that daytime distributions are limited by activities of their visual predators (e.g. Culp et al. 1991; see also Lima \& Dill 1990 for review on effects of light intensity on predator activity and prey distribution). Second, grass shrimp and killifish both occur outside the shallow zone in winter and early spring (Ruiz \& Everett unpubl. data), coinciding with a time when predators are relatively low in abundance (see also Hines et al. 1990) or very small in size.

In contrast to the other shallow zone species, Crangon septemspinosa were often found in the mid and deep zones. Predation risk as a function of depth was not measured for this species. The predators of $C$. 
septemspinosa, and the relative abundance of predators among depth zones, were likely to be similar to those of grass shrimp due to size similarity of the 2 species. However, the common habit of burial may allow C. septemspinosa to utilize the deep zone more often than other shallow zone species, which bury much less frequently than the former (pers obs.). Specifically, burial may reduce the risk of predation experienced by surface-dwelling species, operating just as depth of burial does for some invertebrates in soft-sediment communities (e.g. Virnstein 1979, Zwarts \& Wanink 1989, Barshaw \& Abele 1990a)

The mid zone species probably experienced a similar depth gradient in predation risk to that observed for the shallow zone species, due to similarity in sizes. However, the 2 groups may differ in their utilization of structure, which can modify predation risk (e.g. Heck \& Thoman 1981, Peterson 1982, Mittelbach 1986, Savino \& Stein 1989). Although SAV and oyster bars were absent at CHB, small twigs and branches (2 to $6 \mathrm{~cm}$ diameter) were occasionally present in the shallow and mid zones, and were very rare in deeper water. Rhithropanopeus harrisii, Apeltes quadracus, and Gobisoma bosci are often associated with structures such as SAV, oyster reefs, wood pilings, and woody debris (Wells 1961, Orth \& Heck 1980, Heck \& Thoman 1984, Lippson \& Lippson 1984, Williams 1984, Rozas \& Odum 1987a, Everett \& Ruiz 1993). The fish species utilize such habitat structure to establish mating territories and nest sites (Hildebrand \& Schroeder 1972, Lippson \& Lippson 1984, FitzGerald \& Wootton 1986), and, therefore, may be more dependent on structure compared to shallow zone species. Mudcrabs may also be especially dependent upon structure, as refuge, due to their low mobility.

\section{Historical importance of nearshore shallows}

Historically, SAV and oyster reefs have provided structural refuge from predation in deeper water (>1 m) for many epibenthic species in estuaries (e.g. Coen et al. 1981, Heck \& Thoman 1981, Dauer et al. 1982, Arnold 1984, Heck \& Wilson 1987, Rozas \& Odum 1988). Recent declines in SAV abundance for Chesapeake Bay, and elsewhere (see 'Introduction'), undoubtedly caused many significant changes to estuarine ecosystem function, including changes in population and community characteristics of associated fauna (e.g. Heck \& Thoman 1984, Orth et al. 1984, Muehlstein 1989). With few exceptions (Stauffer 1937. Rasmussen 1977, Stevenson \& Confer 1978, Perry \& Uhler 1988), these changes have not been examined quantitatively. The long-term decline in Chesapeake Bay oyster reefs (Sindermann 1968), also an important habitat for many animal species (Wells 1961, Bahr \& Lanier 1981, Lippson \& Lippson 1984), accentuates the potential for changes in population and community processes due to SAV declines alone.

Our study indicates a shift in depth distribution has occurred for epifaunal crustaceans and fish with changes in available habitat structure. In the presence of SAV, past studies found that Palaemonetes pugio and Fundulus spp. were common in waters $>1 \mathrm{~m}$ depth (e.g. Heck \& Orth 1980, Orth \& Heck 1980, Heck \& Thoman 1984, Heck et al. 1989). However, in the absence of SAV, these species are now restricted primarily to a shallow $(<35 \mathrm{~cm})$ depth zone along the shoreline. This shift in distribution is further illustrated by the differences in densities that we found among depth zones at BI, with and without SAV. Similarly, other species commonly associated with SAV or oyster bars $>1 \mathrm{~m}$ deep (Crangon septemspinosa, Rhithropanopeus harrisii, Apeltes quadracus and Gobisoma bosci; Wells 1961, Heck \& Orth 1980, Orth \& Heck 1980, Heck \& Thoman 1984) were most abundant in depths $<70 \mathrm{~cm}$ at our study site. The nearshore shallows provide both refuge from predation and an important structural habitat created by woody debris (Everett \& Ruiz 1993). Whether the role of woody debris in Chesapeake Bay is a recent change following the demise of SAV and oyster reefs is not clear.

We predict that many other attributes of animal populations have been impacted by the demise of SAV and oyster habitats. Based upon the disparity in animal densities between vegetated and non-vegetated sediments (e.g. Orth et al. 1984, Ferrell \& Bell 1991), the absolute abundance of some species may have declined with the loss of SAV. Furthermore, accompanying a shift in habitat utilization, changes in the demography of populations may have occurred (e.g. Mittelbach 1986, Werner 1986). Given the functional importance of grass shrimp and killifish, both as predators and prey in the Chesapeake Bay community, any of these changes may have cascading effects (sensu Carpenter et al. 1985) on many community processes (e.g. Posey \& Hines 1991). Quantitative exploration of these consequences is still in its infancy.

Acknowledgements. This research was only made possible by the arduous efforts of many people. In particular, we wish to acknowledge the valuable contributions of $\mathrm{K}$. Ruffin and $\mathrm{L}$. Nye, who assisted in all phases of the research. For help in the field we thank G. Braun, A. Dittel, R. Everett, S. Godwin, A. Innis, S. Kissling, M. Kramer, M. Paepke, M. Poteet, H. Roffey, $T$. Steelman, E. Townsend and L. Wiechert. For help in the design and construction of cylinders, we thank J. Ridlon and $T$ Steelman. This research was supported by Smithsonian Scholarly Studies Program grants (\#123ES002 to G.M.R. and A.H.H., \#123ES904 to A.H.H. and M.H.P.), a Smithsonian Environmental Sciences Program grant to A.H.H., and NSF grant OCE-9000483 to A.H.H. 


\section{LITERATURE CITED}

Arnold, W. S. (1984). The effects of prey size, predator size, and sediment composition on the rate of predation of the blue crab, Callinectes sapidus Rathbun, on the hard clam Mercenaria (Linne). J. exp mar. Biol. Ecol. 80: 207-219

Bahr, L. M., Lanier, W. P. (1981). The ecology of intertidal oyster reefs of the South Atlantic coast: a community profile. U.S. Fish Wildl. Serv., Office of Biol. Ser., FWS/OBS-81/15

Barshaw, D. E., Able, K. W. (1990a). Deep burial as a refuge for lady crabs Ovalipes ocellatus: comparisons with blue crabs Calinectes sapidus. Mar. Ecol. Prog. Ser. 66: 75-79

Barshaw, D. E., Abele, K. W. (1990b). Tethering as a technique for assessing predation rates in different habitats: an evaluation using juvenile lobsters Homarus americanus. Fish. Bull. U.S. 88: 415-417

Bayley, S., Stotts, V. D., Springer, P. R., Steenis, J. (1978). Changes in submerged aquatic macrophyte populations at the head of Chesapeake Bay, 1958-1975. Estuaries 1: $73-84$

Bell, S. S., Coull, B. C. (1978). Field evidence that shrimp predation regulates meiofauna. Oecologia 35: 141-148

Bell, S. S., Pollard, D. A. (1989). Ecology of fish assemblages and fisheries associated with seagrasses. In: Larkum, A. W. D., McComb, A. J., Shepherd, S. A. (eds.) Biology of seagrasses. Elsevier, Oxford, p. 565-609

Bishop, J. M., Kahn, M. H. (1991). Depth as a factor in abundance and size of juvenile panaeid shrimps in the absence of estuaries and marshes. Mar. Biol. 109: 103-114

Boesch, D. F., Turner, R. E. (1984). Dependence of fishery species on salt marshes: the role of food and refuges. Estuaries 7: 460-468

Carpenter, S. R, Kitchell, J. F., Hodgson, J. R. (1985). Cascading trophic interactions and lake productivity. BioSci. 35: 634-639

Coen, L. D., Heck, K. L. Jr, Abele, L. G. (1981). Experiments on competition and predation among shrimps of seagrass meadows. Ecology 62: 1484-1493

Connell, J. H. (1972). Community interactions on marine rocky intertidal shores. A. Rev. Ecol. Syst. 3: 169-192

Culp, J. M., Glozier, N. E., Scrimgeour, G. J. (1991). Reduction of predation risk under the cover of darkness: avoidance responses of mayfly larvae to a benthic fish. Oecologia 86: $163-169$

Dauer, D. M., Tourtellotte, G. H., Ewing, R. M. (1982). Oyster shells and artificial worm tubes: the role of refuges in structuring benthic communities of the lower Chesapeake Bay. Int. Revue ges. Hydrobiol. 67: 661-677

de Vlas, J (1979). Annual food intake by plaice and flounder in a tidal flat area of the Dutch Wadden Sea, with special reference to consumption of regenerating parts of macrobenthic prey. Neth. J. Sea Res. 13: 117-153

Eggleston, D. B., Lupcius, R. N., Hines, A. H. (1992). Densitydependent predation by blue crabs upon infaunal clam species with contrasting distribution and abundance patterns. Mar. Ecol. Prog. Ser. 85: 55-68

Everett, R. A., Ruiz, G. M. (1993) Coarse woody debris as refuge from predation in aquatic communities: an experimental test. Oecologia 93: 475-486

Ferrell, D. J., Bell, J. D. (1991). Differences among assemblages of fish associated with Zostera capricomi and bare sand over a large spatial scale. Mar Ecol. Prog. Ser. 72 : $15-24$

Fitz, H. C. (1990). The utilization of a salt marsh estuary by the blue crab, Callinectes sapidus. Ph.D. dissertation, University of Georgia, Athens

Fitz, H. C., Wiegert, R. G. (1991). Utilization of the intertidal zone of a salt marsh by the blue crab Callinectes sapidus: density, return frequency, and feeding habits. Mar. Ecol. Prog. Ser. 76: 249-260

FitzGerald, G. J., Wootton, R. J. (1986). Behavioral ecology of sticklebacks. In: Pitcher, T. J. (ed.) The behavior of teleost fishes. Johns Hopkins Univ. Press, Baltimore, p. 409-432

Foster, S. A., Garcia, V. B., Town, M. Y. (1988). Cannibalism as the cause of an ontogenetic shift in habitat use by fry of the threespine stickleback. Oecologia 74: 577-585

Fraser, D. F., Emmons, E. E. (1984). Behavioral response of blacknose dace (Rhinichthys atratulus) to varying densities of predatory creek chub (Semotilus atromaculatus). Can. J. Fish Aquat. Sci. 41:364-370

Gibson, R. N. (1973). The intertidal movements and distribution of young fish on a sandy beach with special reference to the plaice (Pleuronectes platessa L.). J. exp. mar. Biol. Ecol. 12: 79-102

Gibson, R. N. (1982). Recent studies on the biology of intertidal fishes. Oceanogr. mar. Biol. A. Rev. 20: 363-414

Gibson, R. N. (1986). Intertidal teleosts: life in a fluctuating environment. In: Pitcher, T. J. (ed.) The behavior of teleost fishes. Johns Hopkins Univ. Press, Baltimore, p. 388-408

Haefner, P. A. (1976). Seasonal distribution and abundance of sand shrimp Crangon septemspinosa in the York River-Chesapeake Bay estuary. Chesapeake Sci. 17 : 131-134

Hamilton, P. V. (1976). Predation of Littorina irrorata by Callinectes sapidus. Bull mar. Sci. 26: 403-409

Han, G. (1974). Salt balance and exchange in the Rhode River, a tributary embayment to the Chesapeake Bay. Ph.D. dissertation, Johns Hopkins Univ., Baltimore

Harvey, B. C. (1991). Interactions among stream fishes: predator-induced habitat shifts and larval survival. Oecologia 87: $29-36$

Harvey, B. C., Cashner, R. C., Matthews, W. J. (1988). Differential effects of largemouth and smallmouth bass on habitat use by stoneroller minnows in stream pools. J. Fish Biol. 33: 481-487

Heck, K. L. Jr, Orth, R. J. (1980). Structural components of eelgrass (Zostera marina) meadows in the lower Chesapeake Bay - decapod Crustacea. Estuaries 3: 289-295

Heck, K. L. Jr, Thoman, T. A. (1981). Experiments on predator- prey interactions in vegetated aquatic habitats. J. exp. mar. Biol. Ecol. 53: 125-134

Heck, K. L. Jr, Thoman, T. A. (1984). The nursery role of seagrass meadows in the upper and lower reaches of the Chesapeake Bay. Estuaries 7: 70-92

Heck, K. L. Jr, Wilson, K. A. (1987). Predation rates on decapod crustaceans in latitudinally separated seagrass communities: a study of spatial and temporal variation using tethering techniques. J. exp. mar. Biol. Ecol. 107: $87-100$

Heck, K. L. Jr, Able, K. W., Fahay, Ni. P., Roman, C. T. (1989). Fishes and decapod crustaceans of Cape Cod eelgrass meadows: species composition, seasonal abundance patterns and comparison with unvegetated substrates. Estuaries 12: 59-65

Hildebrand, S. F., Schroeder, W. C. (1972). Fishes of Chesapeake Bay. I F. H. Publications, Inc., Neptune, NJ

Hines, A. H., Osgood, K. E., Miklas, J. J. (1985). Semilunar reproductive cycles in Fundulus heteroclitus (Pisces: Cyprinodontidae) in an area without lunar tidal cycles. Fish. Bull. US: 83:465-472

Hines, A. H., Haddon, A. M., Wiechert, L. A. (1990). Guild structure and foraging impact of blue crabs and epibenthic fish in a subestuary of Chesapeake Bay. Mar. Ecol. Prog. Ser, 67: 105-126 
Hines, A. H., Haddon, P. J., Miklas, J. J., Wiechert, L. A. Haddon, A. M. (1987a). Estuarine invertebrates and fish sampling design and constraints for long-term measurements of population dynamics. In: Boyle, T. (ed.) Longterm monitoring in aquatic ecosystems. Am. Soc. Test. Mater., Philadelphia, p. 140-164

Hines, A. H., Lipcius, R. N., Haddon, A. M. (1987b). Population dynamics and habitat partitioning by size, sex, and molt stage of blue crabs Callinectes sapidus in a subestuary of central Chesapeake Bay. Mar. Ecol. Prog. Ser. 36: $55-64$

Holomuzki, J. R. (1986). Effect of microhabitat on fitness components of larval tiger salamanders, Ambystoma tigrinum nubulosum. Oecologia 71: 142-148

Innis, A. (1992). Microhabitat segregation of juvenile fish in shallow water marshes. M.Sc thesis, Univ. of North Carolina, Wilmington

Jenni, D. A. (1969). A study of the ecology of four species of herons during the breeding season at Lake Alice, Alachua County, Florida. Ecol, Monogr. 39: 245-270

Kemp, W. M., Boynton, W. R., Twilley, R. R. (1984). Influences of submersed vascular plants on ecological processes in upper Chesapeake Bay. In: Kennedy, V. S. (ed.) The estuary as a filter. Academic Press, Orlando, p. 367-394

Kneib, R. T. (1982). The effects of predation by wading birds (Ardeidae) and blue crabs (Callinectes sapidus) on the population size structure of the common mummichog Fundulus heteroclitus. Estuar. coast. Shelf Sci. 14: 159-165

Kneib, R. T. (1984a). Patterns in the utilization of the intertidal salt marsh by larvae and juveniles of Fundulus heteroclitus (Linneaus) and Fundulus luciae (Baird). J. exp. mar Biol. Ecol. 83: 41-51

Kneib, R. T. (1984b). Patterns of invertebrate distribution and abundance in the intertidal salt marsh: causes and questions. Estuaries 7: 392-412

Kneib, R. T (1985). Predation and disturbance by grass shrimp, Palaemonetes pugio Holthuis, in soft-substrate benthic invertebrate assemblages. J. exp. mar. Biol. Ecol. 93: $91-102$

Kneib, R. T (1987). Seasonal abundance, distribution and growth of postlarval and juvenile grass shrimp (Palaemonetes pugio) in a Georgia, USA, salt marsh Mar. Biol. 96: $215-223$

Kneib, R. T. (1988). Testing for indirect effects of predation in an intertidal soft-bottom community. Ecology 69: $1795-1805$

Kuipers, B. (1973). On the tidal migration of young plaice (Pleuronectes platessa) in the Wadden Sea. Neth. J. Sea Res. 6: 376-388

Lima, S. L., Dill, L. M. (1990). Behavioral decisions made under the risk of predation: a review and prospectus. Can. J. Zool. 68: 619-640

Lippson, A. J., Lippson, R. L. (1984). Life in Chesapeake Bay. Johns Hopkins Univ. Press, Baltimore

Macer, C. T (1967). The food web in Red Wharf Bay (North Wales) with particular reference to young plaice (Pleuronectes platessa). Helgoländer wiss. Meeresunters. 15: $560-573$

McIvor, C. C., Odum, W. E. (1988). Food, predation risk, and microhabitat selection in a marsh fish assemblage. Ecology 69: 1341-1351

Mittelbach, G. (1986). Predator-mediated habitat use: some consequences for species interactions. Environ. Biol. Fish. 16: $159-169$

Muehlstein, L. K. (1989). Perspectives on the wasting disease of eelgrass Zostera marina. Dis. aquat. Org. 7 : $211-221$
Nixon, S. W., Oviatt, C. A. (1973). Ecology of a New England salt marsh. Ecol. Monogr. 43: 463-498

Orth, R. J., Heck, K. L. Jr (1980). Structural components of eelgrass (Zostera marina) meadows in the lower Chesapeake Bay - fishes. Estuaries 3: 278-288

Orth, R. J., Heck, K. L. Jr, van Montfrans, J. (1984). Faunal communities in seagrass beds: a review of the influence of plant structure and prey characteristics on predator-prey relationships. Estuaries 7: 339-350

Orth, R. J., Moore, K. A. (1984). Distribution and abundance of submerged aquatic vegetation in Chesapeake Bay: an historical perspective. Estuaries 7: 531-540

Orth, R. J, van Montfrans, J. (1987). Utilization of a seagrass meadow and tidal marsh creek by blue crabs Callinectes sapidus. [. Seasonal and annual variations in abundance with emphasis on post-settlement juveniles. Mar. Ecol. Prog. Ser. 41: 283-294

Pérès, J. M., Picard, J. (1975). Causes of decrease and disappearance of the seagrass Posidonia oceanica on the French Mediterranean coast. Aquat. Bot. 1: 133-139

Perry, M. C., Uhler, F. M. (1988). Food habits and distribution of wintering canvasbacks, Aythya valisineria, on Chesapeake Bay. Estuaries 11:57-67

Peterson, C. H. (1979). Predation, competitive exclusion, and diversity in the soft-sediment benthic communities of estuaries and lagoons. In: Livingston, R. S. (ed.) Ecological processes in coastal and marine systems. Plenum Press, New York, p. 233-264

Peterson, C. H. (1982). Calm predation by whelks (Busycon spp.): experimental tests of the importance of prey size, prey density, and seagrass cover. Mar. Biol. 66: 159-170

Peterson, C. H., Quammen, M. L. (1982). Siphon nipping: its importance to small fishes and its impact on growth of the bivalve Protothaca staminea (Conrad). J. exp. mar. Biol. Ecol. 63: 249-268

Posey, M. H., Hines, A. H. (1991). Complex predator-prey interactions within an estuarine benthic community. Ecology 72: 2155-2169

Power, M. E., Matthews, W. J., Stewart, A. J. (1985). Grazing minnows, piscivorous bass, and stream algae: dynamics of a strong interaction. Ecology 66: 1448-1456

Rasmussen, E. (1977). The wasting disease of eelgrass (Zostera marina) and its effects on environmental factors and fauna. In: McRoy, P. C., Helfferich, C. (eds ) Seagrass ecosystems: a scientific perspective. Marcel Dekker Inc., New York, p. 1-51

Reise, K. (1978). Experiments on epibenthic predation in the Wadden Sea. Helgoländer wiss. Meeresunters. 31: 51-101

Roundtree, R. A., Able, K. W. (1992). Fauna of polyhaline subtidal marsh creeks in souther New Jersey: composition, abundance and biomass. Estuaries 15: 171-185

Rozas, L. P., Hackney, C. T. (1984). Use of oligohaline marshes by fishes and macrofaunal crustaceans in North Carolina. Estuaries 7: 213-224

Rozas, L. P., Odum, W. E. (1987a). Fish and macrocrustacean use of submerged plant beds in tidal freshwater marsh creeks. Mar. Ecol. Prog. Ser. 38: 101-108

Rozas, L. P., Odum, W. E. (1987b). The role of submerged aquatic vegetation in influencing the abundance of nekton on contiguous tidal fresh-water marshes. J. exp. mar. Biol. Ecol. 114: 289-300

Rozas, L. P., Odum, W. E. $(1987 \mathrm{c})$. Use of tidal freshwater marshes by fishes and macrofaunal crustaceans along a marsh stream-order gradient. Estuaries 10: 36-43

Rozas, L. P., Odum, W. E. (1988). Occupation of submerged aquatic vegetation by fishes: testing the roles of food and refuge. Oecologia 77: 101-106 
Savino, J F., Stein, R. A. (1989). Behavioural interactions between fish predators and their prey: effects of plant density. Anim. Behav. 37: 311-321

Schlosser, I. J. (1987). The role of predation in age- and size-related habitat use by stream tishes. Ecology 68: $651-659$

Schlosser, I. J. (1988a). Predation rates and the behavioral response of adult brassy minnow (Hybognathus hankinsoni) to creek chub and smallmouth bass predators. Copeia 1988: $691-697$

Schlosser, I. J. (1988b). Predation risk and habitat selection by two size classes of a stream cyprinid: experimental test of a hypothesis. Oikos 52: $36-40$

Schmelz, G. S. (1964). A natural history of the mummichog, Fundulus heteroclitus, in Canary Creek marsh. M.Sc. thesis, Univ. of Delaware, Newark

Schwartz, F. J. (1965). Age, growth, and egg complement of the stickleback Apeltes quadracus at Solomons, Maryland. Chesapeake Sci. 6: 116-118

Shepherd, S. A., McComb, A. J., Buthuis, D. A., Neverauskas, $V$., Steffensen, D. A., West, R. (1989). Decline of seagrasses. In: Larkum, A. W. D., McComb, A. J., Shepherd, S. A. (eds.) Biology of seagrasses. Elsevier, Amsterdam, p. $346-394$

Siegel, S., Castellan, N. J. Jr (1988). Nonparametric statistics McGraw-Hill, Inc., Mexico City

Sindermann, C. J. (1968). Oyster mortalities, with particular reference to Chesapeake Bay and the Atlantic coast of North America. U.S. Fish Wildl. Serv. Spec. Sci. Rep.- Fish. 569: $1-10$

Smith, L. D. (1990). The frequency and ecological consequences of limb autotomy in the blue crab. Callinectes sapidus Rathbun. Ph.D. dissertation, Univ. of Maryland, College Park

Snedecor, G. W., Cochran, W G. (1978). Statistical methods. Iowa State Univ. Press, Ames

Sogard, S. M., Able, K. W. (1991). A comparison of eelgrass, sea lettuce macroalgae, and marsh creeks as habitats for epibenthic fishes and decapods. Estuar. coast. Shelf Sci. 33: 501-519

Sokal, R. R., Rohlf, F. J. (1981). Biometry. W. H. Freeman and Company, New York

Southwick, C. H., Pine, F. W (1975). Abundance of submerged vascular vegetation in the Rhode River from 1966 to 1973. Chesapeake Sci. 16: 147-151

Stauffer, R. C. (1937). Changes in the invertebrate community of a lagoon after disappearance of the eel grass. Ecology 18: $427-431$

Stevenson, J. C., Confer, N. M. (1978). Summary of available information on Chesapeake Bay submerged vegetation. U.S. Dept. of Interior, Annapolis, FWS/OBS-78/66

Summerson, H. C. Peterson, C. H. (1984). Role of predation in organizing benthic communities of a temperate-zone seagrass bed. Mar. Ecol. Prog. Ser. 15:63-77

This article was presented by C. H. Peterson, Morehead City, N. Carolina, USA
Townsend, E. C. (1991). Depth distribution of the grass shrimp palaemonetes pugio in two contrasting tidal creeks in North Carolina and Maryland. M.S. thesis, Univ. of North Carolina, Wilmington.

Underwood, A. J. (1979). The ecology of intertidal gastropods. Adv. mar. Biol. 16: 111-210

Valiela, I., Wright, J. E., Teal, J M., Volkman, S. B. (1977) Growth, production and energy transformations in the saltmarsh killifish, Fundulus heteroclitus. Mar. Biol. 40: $135-144$

Vaughn, C. C., Fisher, F. M. (1988). Vertical migration as a refuge from predation in intertidal marsh snails: a field test. J. exp. mar. Biol. Ecol. 123: 163-176

Virnstein, R. W. (1979). Predation on estuarine infauna: response patterns of component species. Estuaries 2: 69-86

Watanabe, J. M. (1984). The influence of recruitment, competition, and benthic predation on spatial distributions of three species of kelp forest gastropods (Trochidae: Tegula). Ecology 65: 920-936

Weinstein, M. P. (1979). Shallow marsh habitats as primary nurseries for fishes and shellfish, Cape Fear River, North Carolina. Fish. Bull. U.S. 77: 339-357

Wells, H. W. (1961). The fauna of oyster beds, with special reference to the salinity factor. Ecol. Monogr. 31: 239-266

Welsh, B. L. (1975). The role of grass shrimp, Palaemonetes pugio, in a tidal marsh ecosystem. Ecology 56: 513-530

Werner, E. E. (1986). Species interactions in freshwater communities. In: Diamond, J., Case, T. J. (eds.) Community ecology. Harper and Row, New York, p. 344-357

Werner, E. E., Gilliam, J. F., Hall, D. J., Mittelbach, G. G (1983). An experimental test of the effects of predation risk on habitat use in fish. Ecology 64: 1540-1548

Werner, E. E., Hall, D. J. (1988). Ontogenetic habitat shifts in bluegill: the foraging rate - predation risk trade-off Ecology 69: 1352-1366

West, D. L., Williams, A. H. (1986). Predation by Callinectes sapidus (Rathbun) within Spartina alterniflora (Loisel) marshes. J. exp. mar. Biol. Ecol. 100: 75-95

Williams, A. B. (1984). Shrimps, lobsters, and crabs of the Atlantic coast of the eastern United States, Maine to Florida. Smithsonian Inst. Press, Washington, DC

Wilson, K. A. (1989). Ecology of mangrove crabs: predation, physical factors and refuges. Bull. mar. Sci. 44: 263-273

Wilson, K. A., Heck, K. L. Jr, Able, K. W. (1987). Juvenile blue crab, Callinectes sapidus, survival: an evaluation of eelgrass, Zostera marina, as refuge. Fish. Bull. U.S. 85: $53-58$

Zimmerman, R. J., Minello, T. J., Zamora, G. J (1984). Selection of vegetated habitat by brown shrimp, Panaeus aztecus, in a Galveston Bay salt marsh. Fish. Bull. U.S. 82; $325-336$

Zwarts. L., Wanink, J. (1989). Siphon size and burying depth in deposit- and suspension-feeding benthic bivalves. Mar. Biol. 100: 227-240

Manuscript first received: July 29, 1992

Revised version accepted: April 15, 1993 